\title{
EDITORIAL
}

\section{Abordagens críticas para o estudo do digital e da televisão}

RuMoRes, revista científica on-line dedicada aos estudos de comunicação, linguagem e mídias, apresenta em sua vigésima edição artigos que se concentram sobre uma visada crítica principalmente em relação aos meios digitais, com o dossiê Fronteiras críticas das mídias digitais, e à televisão, nos artigos de temáticas livres reunidos na edição. Temos o orgulho ainda de, com a presente edição, marcarmos nove anos de produção da revista, procurando sempre retratar tendências e fomentar o debate em seu campo de atuação. Podemos dar conta, olhando desde a primeira edição, de uma variedade de objetos e possibilidades teóricas e, para além disso, seu deslocamento ao longo do tempo. Ademais, notamos grande diversidade de autores, instituições, titulações, regiões do país e perfis dos professores, pós-graduandos e pesquisadores que contribuíram com a revista ao longo desses anos. A eles, agradecemos pela confiança e, aos leitores, pelo acompanhamento de nosso trabalho.

O dossiê Fronteiras críticas das mídias digitais, que inaugura a edição, apresenta artigos que avaliam as atuais possibilidades desses meios tanto quanto seus efeitos polêmicos ou nocivos. Definitivamente não podemos mais dizer que estamos num primeiro momento de contato com o digital, mas em tempos de debate sobre outras tomadas de posição em relação a ele, as identidades dos sujeitos que em torno dele se mobilizam, suas possibilidades de apropriação de recursos e linguagens. Somando-se a isso, vemos crescer um profícuo debate sobre privacidade e controle de informação e, ainda, o alerta para a necessidade de um letramento para o digital, enquanto grande parte da população brasileira (segundo dados de 2016, aproximadamente metade das pessoas) ainda não 
tem nem mesmo o acesso físico às redes.

O dossiê inicia-se com "Smart: uma pesquisa sobre as internets", resultado da conferência de Frédéric Martel, da Universidade Zürcher Hochschule der Künste (ZHdK), Suíça, realizada na Pontifícia Universidade Católica de São Paulo (PUCSP), evento promovido pelos grupos de pesquisa Comunicação e Criação nas Mídias, daquela instituição, e pelo MidiAto, editor desta publicação. O texto tenta romper especialmente com uma ideia de que a internet propicia uma conexão coletiva ampla e uma uniformidade, mostrando a existência de internets no plural e a necessidade de uma curadoria inteligente. Estamos disponibilizando trechos da conferência em vídeos, que circularão em nossas redes sociais (Facebook e YouTube) ${ }^{1}$, agregando conteúdos para além daqueles textuais.

A pluralidade dos meios digitais está também na variedade de materiais e na especial possibilidade criativa de mixagem. A coordenadora do mencionado grupo de pesquisa da PUC-SP, Lúcia Leão, também oferece sua contribuição, com o trabalho "A arte do remix: uma anarqueologia dos processos de criação em mídias digitais". Outra característica normalmente atribuída às conexões em rede está no ambiente de ligação entre as pessoas e nas novas possibilidades de interação com o outro. Na sequência do dossiê, temos o trabalho de Alex Primo, da Universidade Federal do Rio Grande do Sul (UFRGS), com o provocativo título "E se Aristóteles usasse o Facebook? Uma genealogia da amizade", analisando formas atuais desse afeto há tempos tematizado. A relação pessoa a pessoa pode favorecer a proximidade com instituições, entidades e governos em processos de modo a desafiar formas de representatividade do público. Temos, assim, o trabalho "Usos do entretenimento como estratégia de visibilidade política na página da prefeitura de Curitiba no Facebook", uma coautoria entre Luís Mauro Sá Martino e Tayra Carolina Aleixo, da Faculdade Cásper Líbero (SP).

Da mesma forma que a internet é calcada num imaginário inclusivo, 
podemos tomar como hipótese que ela é responsável por reforçar - e até mesmo criar - novas formas de desigualdades já presentes socialmente. Seguindo com o dossiê, numa preocupação com a exclusão social e/ou digital, temos o trabalho de Massimo Ragnedda e Maria Laura Ruiu, pesquisadores da Universidade de Northumbria, denominado "Exclusão digital: como é estar do lado errado da divisão digital". Podemos pensar que estar incluído significa uma exposição para além da possibilidade narrativa de nossos próprios dados. Com a preocupação pela vigilância e compartilhamento on-line, Athina Karatzogianni, da Universidade de Leicester, e o pesquisador Martin Gak, veem a única saída pelo hackeamento cidadão em "Hackear ou ser hackeado: o quase-totalitarismo das redes de segurança globais". E para além de dados, como pensar a possibilidade de disponibilização de conteúdos realmente relevantes e de interesse? Carolina Frazon Terra, da Escola de Comunicações e Artes da Universidade de São Paulo (ECA-USP), desafia tal produção em "A 'buzzfeedização' da comunicação das organizações no ambiente digital".

Na sequência desta edição, tratamos de uma crítica profusa das produções televisivas, ainda mais necessária e relevante hoje. O telespaço público brasileiro é analisado em termos de modernizações, mas também da manutenção de ranços ditatoriais e de desarticulação política em "Televisão brasileira e ditadura militar: tudo a ver com o que está aí até hoje", de Eugênio Bucci. Entre as possibilidades de criação estética e um olhar para a educação e para a cidadania, vamos do remix digital ao remake em "O diálogo entre estética e ética na produção de sentidos de educação e cidadania na telenovela Meu Pedacinho de Chão", de Cristina Mungioli em parceria com Gustavo Amaral. E seguimos somando as questões estéticas e politicas na tentativa de observar as formas de representação do popular em "Imagem e estética na construção discursiva do popular: reflexões sobre duas telenovelas de João Emanuel Carneiro", de Rosana Mauro.

Há ainda trabalhos que se diversificam pelo feminino, pela autoria e pelo documentário voltando ao telejornalismo e aos jornalismos possíveis. Josefina 
de Fatima Tranquilin-Silva trata da campanha feminista na web em "Corpos falantes e rostos (in)visíveis: corpo, sexualidade e feminismo em 'Moça, você é machista'". Márcio Andrade apresenta "De Eric para Mário - sobre autoria, autobiografia e representações do presente em um documentário de busca", analisando diferentes modos de representação de si. A presença da música em documentários de Eduardo Coutinho é trabalhada no artigo "Música, memória e história na obra de Eduardo Coutinho", de Renato Levi. Encerrando a edição, tentamos buscar aberturas existentes no jornalismo tradicional, com "Telejornalismo, narrativas e representações: um estudo sobre o aniversário da cidade de São Paulo no SPTV", de Vicente William da Silva Darde em coautoria com Fernando Albino Leme. E também vemos a necessidade de entender a prática jornalística em espaços alternativos e suas possibilidades de resistência com "Jornalismos possíveis", de Clarissa Henning.

Ao encerrarmos mais um ano, desejamos aos nossos leitores e leitoras um momento de resistência e esperança, sobretudo em tempos tão conflituosos e, por vezes, sombrios no campo da política e da vida social brasileiras. Desejamos, ainda, que voltemos renovados para dar continuidade a nossas pesquisas, aulas, projetos e parcerias, sem esquecer o espaço fundamental constituído por nossas instituições de ensino, pesquisa e extensão. Que 2017 possa trazer novos ares e abrir perspectivas nas reflexões e práticas por nós realizadas, reafirmando o imprescindível espaço crítico e analítico que dá sentido a nossa atuação. Que os artigos reunidos nesta edição de RuMoRes possam inspirar outras palavras e gerar tramas textuais complexas e profícuas. Boas leituras a tod@s!

Rosana de Lima Soares dezembro de 2016 